\title{
Renal denervation: mechanisms and clinical aspects
}

\author{
Marshall J Heradien ',2, Pieter van der Bijl', Paul A Brink',2 \\ 'Kuils River Hospital, Cape Town, South Africa; ²Department of Medicine, Stellenbosch University, Cape Town, South Africa.
}

\section{ABSTRACT}

Hypertension is a global health issue of paramount importance, which has not spared the African continent where an unacceptably high prevalence of uncontrolled blood pressure prevails among its population. Renal denervation (RD) represents an invasive management option for resistant hypertension, acting via several different physiological pathways - mostly predicated on modification of the renal autonomic nervous system. The evidence base for RD has recently been expanded by three randomised, sham-controlled clinical trials, which demonstrated significant blood pressure reductions under a variety of clinical conditions. In this review, both the renal mechanisms underlying RD, as well as the clinical aspects of its application to hypertension, are discussed.

Keywords: renal denervation; hypertension.

\section{INTRODUCTION}

Hypertension control remains a pressing global health issue, and Africa is no exception in this regard. In a large South African survey (the South African National Health and Nutrition Examination Survey, SANHANES-I), the prevalence of hypertension was $35 \%$ in adults; it has been estimated that $9 \%$ of all deaths in South Africa can be attributed to the complications of hypertension $[1,2]$. Data from the same study recorded only $23 \%$ of hypertensive patients as receiving antihypertensive therapy [2]. In a recent study of more than 10000 individuals in subSaharan Africa, the highest prevalence of uncontrolled hypertension (55.4\% of women and $54.7 \%$ of men) was documented in South Africa (Soweto, an urban settlement of more than 1.5 million people southwest of Johannesburg) [3]. The analysis of serum drug assays in 100 hypertensive patients followed up at a South African tertiary referral centre revealed that 17\% were nonadherent to an angiotensin-converting enzyme inhibitor and $12 \%$ to a calcium channel blocker [4].

Renal denervation (RD) is an emerging therapy for resistant hypertension, predominantly acting via renal mechanisms to lower systemic blood pressure. Three recently published, randomised trials have provided robust evidence for the effectiveness of $R D$ in treating hypertension [5-7]. An advantage of RD in comparison to pharmacotherapy is that its efficacy is independent of patient adherence.

\section{NEURO-RENAL MECHANISMS OF RD}

The afferent renal nerves, predominantly located in the renal pelvis, transmit impulses via the dorsal spinal cord to the central nervous system when activated by stretch forces (Figure I) [8]. Higher centres to which these signals project include the nucleus tractus solitarius, paraventricular nucleus of the hypothalamus, rostral ventrolateral medulla, subfornical organ and the A5 noradrenergic cell group [9-14] (Table I). Renal afferent nerve activity stimulates the central nervous system to increase vasopressin and oxytocin release and leads to activation of efferent sympathetic neurons, which run to the kidneys. Efferent neurons course along paravertebral ganglia and large blood vessels to innervate organs located in the thoracolumbar region. In the heart, sympathetic nerves terminate in the sino-atrial node and 


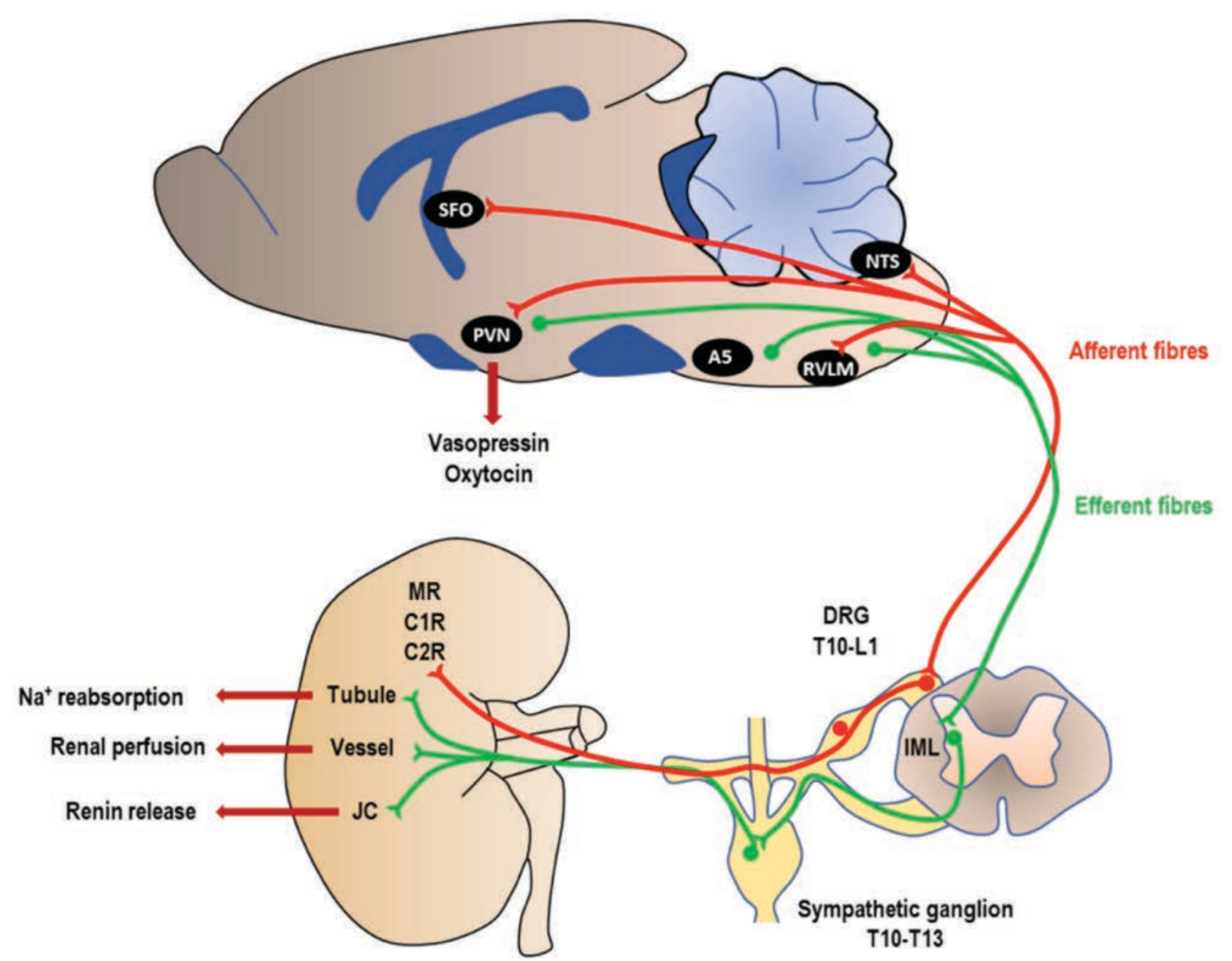

Figure I. Neuro-renal axis and blood pressure regulation. Complex connections between the central nervous system and kidney via the renal nerves include afferent signals, e.g., from renal chemoreceptors, and efferent signals, which regulate blood pressure via hypothalamic (e.g., vasopressin release) and renal (e.g., renin release) mechanisms. Abbreviations: A5, noradrenergic cell group; CIR and C2R, renal chemoreceptors; DRG, dorsal root ganglion; JC, juxtaglomerular cells; IML, intermediolateral cell column; MR, renal mechanoreceptors; NTS, nucleus tractus solitarius; PVN, paraventricular nucleus of the hypothalamus; RVLM, rostral ventrolateral medulla; SFO, subfornical organ. Redrawn from Nishi et al. [8] with permission.

Table I. Central nervous system cell groups related to the neuro-renal axis.

\begin{tabular}{|c|c|}
\hline Cell group & $\begin{array}{l}\text { Central } \\
\text { neurotransmitter(s) } \\
\text { with a postulated } \\
\text { role in blood } \\
\text { pressure control }\end{array}$ \\
\hline Subfornical organ [9] & - Serotonin \\
\hline $\begin{array}{l}\text { Paraventricular nucleus of the hypothalamus } \\
{[10]}\end{array}$ & $\begin{array}{l}\text { - Gamma } \\
\text { - Gluninobutyric acid } \\
\text { - Glumate }\end{array}$ \\
\hline A5 noradrenergic cell group [1 I] & - Catecholamines \\
\hline Rostral ventrolateral medulla [1 I- I3] & $\begin{array}{l}\text { - Catecholamines } \\
\text { - Gamma } \\
\text { - Gminobutyric acid } \\
\text { - Glutamate } \\
\text { - Glycine }\end{array}$ \\
\hline Nucleus tractus solitarius (NTS) [14] & - Adenosine \\
\hline
\end{tabular}

atrioventricular node, in addition to both ventricles. Cardiac sympathetic stimulation increases chronotropy, dromotropy and inotropy, which cumulatively increase cardiac output and systolic blood pressure. Sympathetic nerves emanating from the central nervous system also pass through the stellate ganglia, which play an essential role in the development of tachyarrhythmias, such as ventricular tachycardia and atrial fibrillation [15].

In the lumbar region, efferent sympathetic nerves enter the kidneys via the renal arteries; after arborising alongside the renal artery branches, they course with the vasa vasorum and terminate in the efferent glomerular arteriole, the juxtaglomerular apparatus and renal tubules. Stimulation of the juxtaglomerular apparatus causes renin release, which in turn activates the renin-angiotensin-aldosterone system (RAAS). The end products of RAAS activation, 
angiotensin II (AT-II) and aldosterone, induce vasoconstriction and renal tubular sodium and water retention, respectively. AT-II also exhibits a constrictor effect on the efferent glomerular arteriole, thereby raising intraglomerular pressure and filtration rate. Peripheral vascular resistance is also elevated by AT-II, which increases diastolic blood pressure, cardiac afterload and coronary perfusion.

In the healthy kidney, stretching of the renal pelvis has an inhibitory effect on the efferent renal sympathetic nerves. In the hypo-perfused kidney, however, this inhibitory reflex is attenuated and results in sympatho-excitation, increased cardiac output, augmented glomerular filtration and subsequent adrenal gland activation. Chronic and inappropriate activation of this system elevates systemic blood pressure. Although increased sympathetic tone is not the sole cause of primary hypertension, there is robust evidence that the sympathetic nervous system plays a central role in the pathogenesis of hypertension [16]. The kidneys are therefore central to the pathogenesis of hypertension through autonomic regulation of increased peripheral resistance, sodium and water retention, as well as additional mechanisms [16]. Modification of the neuro-renal axis by disrupting the connection between the central nervous system and kidneys is an attractive therapeutic target, and both anatomical and physiological knowledge of the renal nerve supply support this approach $[17,18]$.

In humans, non-selective surgical splanchnicectomy, which includes RD, was historically performed as a treatment for systemic hypertension [19] but abandoned due to unacceptable side effects, including impotence, orthostatic hypotension and urinary incontinence. The advent of femoral endovascular access and therapies made nonsurgical RD a reality. Radiofrequency energy can be applied to the renal arteries through a dedicated helical catheter, causing thermal damage to the adventitial nerves (Figure 2). Heradien and co-workers recently reported on successful RD performed via brachial and radial artery punctures, which expands the options for vascular access to treat hypertension invasively [20]. Alternative vascular access routes for RD (such as via the radial artery) eliminate the risk of femoral access-related haemorrhage and allow patient discharge on the same day as the procedure. Nonsurgical RD, therefore, exerts its anti-hypertensive effects by inhibiting the neural traffic between the central nervous system and kidneys and has entered the clinical arena.

\section{CLINICAL ASPECTS OF RD}

The SYMPLICITY HTN-2 trial (Table 2) was the first after preclinical and proof-of-concept human studies [2I]. In SYMPLICITY HTN-2, significant decreases (32 $\mathrm{mmHg}$ systolic and $12 \mathrm{mmHg}$ diastolic) in blood pressure were seen in the RD group after 6 months, compared to those receiving drug therapy $(P<0.00 I)[2 I]$. The much anticipated SYMPLICITY HTN-3 study (Table 2), however, could not demonstrate a significant difference in blood pressure reduction between RD treatment and a sham control group $(P=0.98)$ [22]. Numerous limitations of the SYMPLICITY HTN-3 trial have been identified since, e.g. modification of pharmacotherapy during the trial, a large range of operator experience in the $\mathrm{RD}$ procedure, proximal RD without the inclusion of more distal renal artery ablation and the fact that treatment adherence was not monitored objectively. The SPYRAL-HTN-OFF MED, SPYRAL-HTN-ON MED AND RADIANCE-HTN SOLO trials were designed to account for the limitations of the SYMPLICITY HTN-3 study (Table 2). Significant antihypertensive effects of RD were seen in all three of these trials, which revived interest in RD, and substantially bolstered the evidence base for translating this modality into clinical practice. Very recently, the blood pressure lowering effect of RD was confirmed in a large, randomised, sham-controlled trial (SPYRAL HTN-OFF MED Pivotal) [23]. This international, multicentre trial recruited 33 I patients from 44 centres and demonstrated that $\mathrm{RD}$ with a quadripolar radiofrequency denervation catheter (Symplicity Spyral ${ }^{\mathrm{TM}}$ ) significantly lowers ambulatory $(-3.9 \mathrm{mmHg})$ and office blood pressure $(-6.5 \mathrm{mmHg})$ to a greater degree than a sham procedure in hypertensive patients who did not take any blood pressure lowering

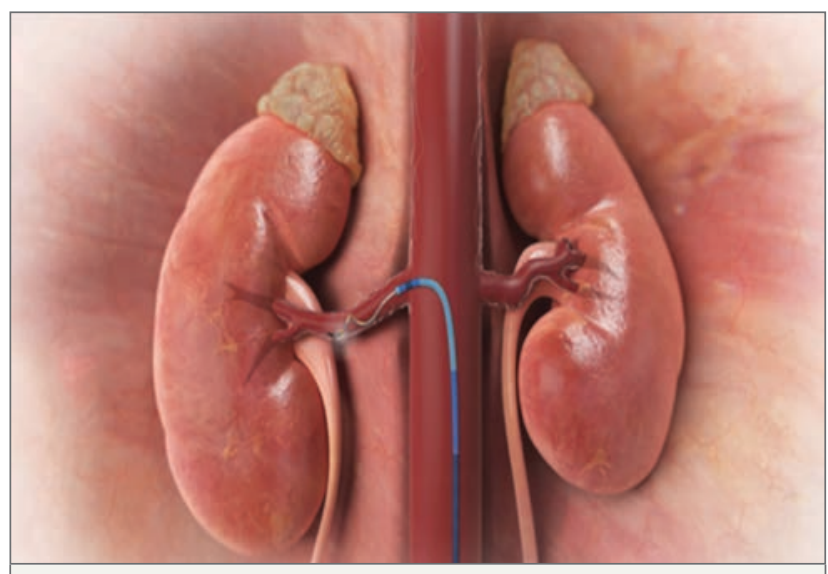

Figure 2. Procedural aspects of renal denervation. A Symplicity Spyral ${ }^{\mathrm{TM}}$ (Medtronic, Galway, Ireland) renal denervation catheter is advanced into the right main renal artery via a femoral puncture, whereafter radiofrequency energy is delivered to the peri-renal sympathetic nerves via the catheter. Reproduced with permission from Medtronic Africa (Midrand, South Africa). 
Table 2. Randomised, sham-controlled trials of renal denervation.

\begin{tabular}{|c|c|c|c|c|c|}
\hline Study & $\begin{array}{c}\text { Year } \\
\text { published }\end{array}$ & $\begin{array}{c}\text { No. of } \\
\text { patients }\end{array}$ & Objective & Primary endpoint & Outcome \\
\hline RADIANCE-HTN SOLO [7] & 2018 & 146 & $\begin{array}{l}\text { Comparison of ultrasound } \\
\text { RD and sham groups for } \\
\text { BP reduction without } \\
\text { pharmacotherapy }\end{array}$ & $\begin{array}{l}\text { Reduction in ambulatory } \\
\text { systolic BP at } 2 \text { months } \\
\text { post-randomisation }\end{array}$ & $P=0.000 I$ in favour of $R D$ \\
\hline SPYRAL HTN-ON MED [6] & 2018 & 80 & $\begin{array}{l}\text { Comparison of } \\
\text { radiofrequency RD } \\
\text { (quadripolar catheter) } \\
\text { and sham groups for BP } \\
\text { reduction in patients with } \\
\text { uncontrolled hypertension } \\
\text { on pharmacotherapy }\end{array}$ & $\begin{array}{l}\text { Reduction in ambulatory BP } \\
\text { at } 6 \text { months }\end{array}$ & $\begin{array}{l}P=0.005 I \text { in favour of } \\
R D \text { for systolic } B P \text { and } P= \\
0.0292 \text { in favour of } R D \text { for } \\
\text { diastolic BP }\end{array}$ \\
\hline SPYRAL HTN-OFF MED [5] & 2017 & 80 & $\begin{array}{l}\text { Comparison of } \\
\text { radiofrequency RD } \\
\text { (quadripolar catheter) } \\
\text { and sham groups for } \\
\text { BP reduction without } \\
\text { pharmacotherapy }\end{array}$ & $\begin{array}{l}\text { Reduction in ambulatory BP } \\
\text { at } 3 \text { months }\end{array}$ & $\begin{array}{l}P=0.04 I 4 \text { in favour of } \\
R D \text { for systolic } B P \text { and } P= \\
0.0024 \text { in favour of } R D \text { for } \\
\text { diastolic BP }\end{array}$ \\
\hline SYMPLICITY HTN-3 [22] & 2014 & 535 & $\begin{array}{l}\text { Comparison of } \\
\text { radiofrequency RD (single } \\
\text { point catheter) and sham } \\
\text { groups for BP reduction } \\
\text { in patients with resistant } \\
\text { hypertension }\end{array}$ & $\begin{array}{l}\text { Reduction in office BP at } 6 \\
\text { months }\end{array}$ & $\begin{array}{l}P=0.98 \text { with no significant } \\
\text { difference between RD and } \\
\text { sham groups }\end{array}$ \\
\hline SYMPLICITY HTN-2 [2I] & 2010 & 106 & $\begin{array}{l}\text { Comparison of } \\
\text { radiofrequency RD (single } \\
\text { point catheter) and sham } \\
\text { groups for BP reduction } \\
\text { in patients with resistant } \\
\text { hypertension }\end{array}$ & $\begin{array}{l}\text { Reduction in office BP at } 6 \\
\text { months }\end{array}$ & $P<0.000$ I in favour of $R D$ \\
\hline
\end{tabular}

Abbreviations: BP, blood pressure; RD, renal denervation.

drugs. There were no major safety concerns noted during a 3-month follow-up period.

Whereas the abovementioned trials were randomised and sham-controlled, several randomised trials without a sham arm have been published (RADIOSOUND-HTN [24], RDN OSA [25], INSPIRED [26], SYMPATHY [27], DENERVHTA [28], PRAGUE-I 5 [29], DENER-HTN [30], SYMPLICITY HTN Japan [3I] and RDN OSLO [32]). While some were in favour of RD, others were not. Registry data on RD have also been collected, e.g. in the Global Symplicity Registry [33], the UK Renal Denervation Affiliation study [34] and the Swedish National Registry [35].

In the SYMPLICITY HTN-3 trial, African-American patients experienced a greater blood pressure reduction in response to sham treatment than other demographic groups - a very intriguing signal which has been ascribed to a greater degree of drug therapy adherence but has not been fully explained [36]. The specific sub-groups of patients who will derive most benefit from RD, including demographic groups, is still largely unknown, and requires further study. The practice of RD on the African continent has not been systematically documented, nor has the efficacy of RD for hypertension been thoroughly studied in the African population. Patients in Africa with resistant hypertension have limited access to RD - as far as the authors are aware, only four private healthcare facilities in South Africa perform RD procedures regularly. A consensus statement on the appropriate use of RD was released by the South African Heart Association and Hypertension Society in 2013. This document proposes that RD be limited to registries or prospective studies, but it was compiled before the results of the SPYRAL-HTN-OFF MED, SPYRAL-HT-ON MED and RADIANCE-HTN $\mathrm{SOLO}$ trials were known. As the first step in RD rollout on the African continent and considering the constrained resources of many African healthcare systems, we propose the establishment of an African RD registry to assess treatment efficacy and safety in African patients. 


\section{CONCLUSIONS}

The kidney and its connections to the central nervous system are pivotal in the regulation of blood pressure and the pathogenesis of systemic hypertension. Disruption of this neuro-renal axis underlies therapeutic RD and is accomplished with trans-arterial access in the contemporary era. Recent trial evidence for the efficacy of RD in the treatment of hypertension has revitalised clinical interest. RD is still infrequently used in Africa but offers hope for mitigating the impact of the very considerable burden of uncontrolled hypertension.

\section{Acknowledgements and conflicts of interest}

$\mathrm{MJH}$ is a recipient of the Hamilton Naki Scholarship and received study support from Medtronic, Inc. The other authors have nothing to disclose.

\section{REFERENCES}

I. Norman R, Gaziano T, Laubscher R, Steyn K, Bradshaw D. Estimating the burden of disease attributable to high blood pressure in South Africa in 2000. S Afr Med J. 2007; 97(8):692-698.

2. Berry KM, Parker WA, McHiza ZJ, Sewpaul R, Labadarios D, Rosen S, et al. Quantifying unmet need for hypertension care in South Africa through a care cascade: evidence from the SANHANES, 20 I I-20 I 2. BMJ Glob Health. 2017; 2(3):e000348.

3. Gomez-Olive FX, Ali SA, Made F, Kyobutungi C, Nonterah E, Micklesfield L, et al. Regional and sex differences in the prevalence and awareness of hypertension: An H3Africa AWI-Gen study across 6 sites in sub-Saharan Africa. Glob Heart. 2017; 12(2):81-90.

4. Jones E, Decloedt E, Blockman M, Sturrock E, Lesosky M, Wiesner L, et al. Assessing antihypertensive adherence with therapeutic drug monitoring. J Hypertens. 20 I 5;33(e-Supplement I):e280

5. Townsend RR, Mahfoud F, Kandzari DE, Kario K, Pocock S, Weber MA, et al. Catheter-based renal denervation in patients with uncontrolled hypertension in the absence of antihypertensive medications (SPYRAL HTN-OFF MED): a randomized, shamcontrolled, proof-of-concept trial. Lancet. 2017; 390( I0108): $2160-2170$

6. Kandzari DE, Böhm M, Mahfoud F, Townsend RR, Weber MA, Pocock $S$, et al. Effect of renal denervation on blood pressure in the presence of antihypertensive drugs: 6-month efficacy and safety results from the SPYRAL HTN-ON MED proof-of-concept randomized trial. Lancet. 2018; 39I (I0137):2346-2355.

7. Azizi M, Schmieder RE, Mahfoud F, Weber MA, Daemen J, Davies J, et al. Endovascular ultrasound renal denervation to treat hypertension (RADIANCE-HTN SOLO): a multicentre, international, single-blind, randomized, sham-controlled trial. Lancet. 2018; 39| ( 0137$): 2335-2345$

8. Nishi EE, Bergamaschi CT, Campos RR. The crosstalk between the kidney and the central nervous system: the role of renal nerves in blood pressure regulation. Exp Physiol. 2015; 100(5):479-484.

9. Takahashi M, Tanaka J. Serotonin release in the subfornical organ area induced by sodium and water intake in the rat. Physiol Behav. 2016; 164(Pt A): 123-128.
10. Dampney RA, Michelini LC, Li DP, Pan HL. Regulation of sympathetic vasomotor activity by the hypothalamic paraventricular nucleus in normotensive and hypertensive states. Am J Physiol Heart Circ Physiol. 2018; 315(5):HI200-HI2|4.

I I. Ding ZQ, Li YW, Wesselingh SL, Blessing WW. Transneuronal labelling of neurons in rabbit brain after injection of herpes simplex virus type I into the renal nerve. J Auton Nerv Syst. 1993; 42( (1):23-31.

12. Bergamaschi C, Campos RR, Schor N, Lopes OU. Role of the rostral ventrolateral medulla in maintenance of blood pressure in rats with Goldblatt hypertension. Hypertension. 1995; 26(6 Pt 2): I I I7-I I 20.

13. Kumagai H, Oshima N, Matsuura T, ligaya K, Imai M, Onimaru H, et al. Importance of rostral ventrolateral medulla neurons in determining efferent sympathetic nerve activity and blood pressure. Hypertens Res. 2012; 35(2): |32-|4|.

14. McClure JM, O'Leary DS, Scislo TJ. Neural and humoral control of regional vascular beds via $\mathrm{AI}$ adenosine receptors located in the nucleus tractus solitarii. Am J Physiol Regul Integr Comp Physiol. 201 I; 300(3):R744-755.

15. Waldron NH, Fudim M, Mathew JP, Piccini JP. Neuromodulation for the treatment of heart rhythm disorders. JACC Basic Transl Sci. 2019; 4(4):546-562.

16. Sheng Y, Zhu L. The crosstalk between autonomic nervous system and blood vessels. Int J Physiol Pathophysiol Pharmacol. 2018; 10(1):17-28.

17. Burnstock G, Loesch A. Sympathetic innervation of the kidney in health and disease: Emphasis on the role of purinergic cotransmission. Auton Neurosci. 2017; 204:4-16.

18. Osborn JW, Foss JD. Renal Nerves and Long-term control of arterial pressure. Compr Physiol. 2017; 7(2):263-320

19. Smithwick RH, Thompson JE. Splanchnicectomy for essential hypertension; results in 1,266 cases. J Am Med Assoc. 1953; I 52(16): I 50 I- I 504.

20. Heradien MJ, Augustyn J, Saaiman A, Brink PA. First reported cases: renal denervation with second-generation multi-electrode catheter via brachial and radial access. Cardiovasc J Afr. 20 I 6; 27( I):53-55.

21. Symplicity HTNI, Esler MD, Krum H, Sobotka PA, Schlaich MP, Schmieder RE, et al. Renal sympathetic denervation in patients with treatment-resistant hypertension (The Symplicity HTN-2 Trial): a randomized controlled trial. Lancet. 2010; 376(9756): I903-1909.

22. Bhatt DL, Kandzari DE, O'Neill WW, D'Agostino R, Flack JM, Katzen $B T$, et al. A controlled trial of renal denervation for resistant hypertension. N Engl J Med. 20 |4; 370( | 5): | 393- |40 |.

23. Böhm M, Kario K, Kandzari DE, Mahfoud F, Weber MA, Schmieder $R E$, et al. Efficacy of catheter-based renal denervation in the absence of antihypertensive medications (SPYRAL HTN-OFF MED Pivotal): a multicentre, randomized, sham-controlled trial. Lancet 2020. Epub before print 2020/03/28. DOI:I0.10 I6/S0 I 40-6736(20)30554-7.

24. Fengler K, Rommel KP, Blazek S, Besler C, Hartung P, von Roeder M, et al. A three-arm randomized trial of different renal denervation devices and techniques in patients with resistant hypertension (RADIOSOUND-HTN). Circulation. 2019; 1 39(5):590-600.

25. Warchol-Celinska E, Prejbisz A, Kadziela J, Florczak E, Januszewicz M, Michalowska l, et al. Renal denervation in resistant hypertension and obstructive sleep apnea: randomized proof-of-concept phase II trial. Hypertension. 2018; 72(2):381-390.

26. Jacobs L, Persu A, Huang QF, Lengele JP, Thijs L, Hammer F, et al. Results of a randomized controlled pilot trial of intravascular renal denervation for management of treatment-resistant hypertension. Blood Press. 2017; 26(6):321-331. 
27. De Jager RL, de Beus E, Beeftink MM, Sanders MF, Vonken EJ, Voskuil M, et al. Impact of medication adherence on the effect of renal denervation: The SYMPATHY Trial. Hypertension. 2017; 69(4):678-684.

28. Oliveras A, Armario P, Clara A, Sans-Atxer L, Vazquez S, Pascual J, et al. Spironolactone versus sympathetic renal denervation to treat true resistant hypertension: results from the DENERVHTA study a randomized controlled trial. J Hypertens. 20 I 6; 34(9): I863- I87 I.

29. Rosa J, Widimsky P, Tousek P, Petrak O, Curila K, Waldauf P, et al. Randomized comparison of renal denervation versus intensified pharmacotherapy including spironolactone in true-resistant hypertension: six-month results from the Prague- 15 study. Hypertension. 2015; 65(2):407-413.

30. Azizi M, Sapoval M, Gosse P, Monge M, Bobrie G, Delsart P, et al. Optimum and stepped care standardised antihypertensive treatment with or without renal denervation for resistant hypertension (DENERHTN): a multicentre, open-label, randomized controlled trial. Lancet. 20I5; 385(998I): 1957-1965.

31. Kario K, Ogawa H, Okumura K, Okura T, Saito S, Ueno T, et al. SYMPLICITY HTN-Japan - first randomized controlled trial of catheter-based renal denervation in Asian patients. Circ J. 2015; 79(6): 1222-1229.

32. Fadl Elmula FE, Hoffmann P, Larstorp AC, Fossum E, Brekke M, Kjeldsen SE, et al. Adjusted drug treatment is superior to renal sympathetic denervation in patients with true treatment-resistant hypertension. Hypertension. 20 14; 63(5):991-999.

33. Böhm M, Mahfoud F, Ukena C, Bauer A, Fleck E, Hoppe UC, et al. Rationale and design of a large registry on renal denervation: the Global SYMPLICITY registry. Eurolntervention. 201 3;9(4):484-492.

34. Sharp AS, Davies JE, Lobo MD, Bent CL, Mark PB, Burchell AE, et al. Renal artery sympathetic denervation: observations from the UK experience. Clin Res Cardiol. 20 I 6; I05(6):544-552.

35. Volz S, Spaak J, Elf J, Jagren C, Lundin C, Stenborg A, et al. Renal sympathetic denervation in Sweden: a report from the Swedish registry for renal denervation. J Hypertens. 20 I 8; 36(I): I 5 I- I58.

36. Brewster LM, Seedat YK. Why do hypertensive patients of African ancestry respond better to calcium blockers and diuretics than to ACE inhibitors and beta-adrenergic blockers? A systematic review. BMC Med. 2013; |1:|4|. DOI: 10.1186/174|-70|5-|1-141. 